\title{
Distinction between Bacterial and Algal Utilization of Soluble Substances in the Sea
}

\author{
By A. L. S. MUNRO \\ Marine Laboratory, Aberdeen \\ AND T. D. BROCK \\ Department of Microbiology, Indiana University, \\ Bloomington, Indiana
}

(Accepted for publication I September 1967)

SUMMARY

The presence of numerous bacteria and diatoms attached to the sand grains of a littoral beach have been shown by fluorescence microscopy. Bacteria and diatoms were found in a viable condition to depths exceeding Io $\mathrm{cm}$. The rate of uptake of $\left[{ }^{14} \mathrm{C}\right]$-acetate was measured over the range I0-5000 $\mu \mathrm{g}$./1. and the results analysed by Michaelis-Menten kinetics. By the use of autoradiography it was shown that the bacteria alone were responsible for the uptake of $\left[{ }^{3} \mathrm{H}\right]$-acetate. It is concluded that algal heterotrophy is negligible in sea waters.

\section{INTRODUCTION}

The available substrate for heterotrophy in the sea comprise both particulate and soluble organic material, the latter predominating by a factor of ten or more (Parsons \& Strickland, 1962). The soluble material is made up of heterogeneous compounds of which only a fraction is likely to contain compounds of low molecular weight. Reliable reports of the concentration of individual compounds are few; however, Siegel \& Degens (I966) have reported a mixture of 17 free amino acids constituting $66 \mu \mathrm{g} . / \mathrm{l}$. in Buzzards Bay, Cape Cod, and Degens, Reuter \& Shaw (1964) reported glucose,

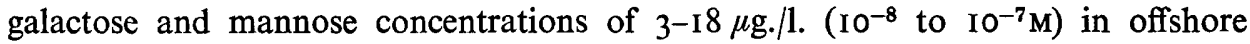
Californian seawaters. Wright \& Hobbie (1965, 1966) and Vaccaro \& Jannasch (1966) described the uptake of single substrates by pure cultures of bacteria at concentrations in excess of $10^{-8} \mathrm{M}$. In a similar survey of four pelagic species of algae, including one known heterotroph, Sloan \& Stickland (I966) concluded that uptake at concentrations of $0.25 \mathrm{mg}$. $\mathrm{C} / 1 .\left(5 \times 10^{-6} \mathrm{M}\right)$ was insufficient to balance even respiratory requirements.

The low concentration of suitable substrates dictates that measurement of heterotrophy within a natural population requires the development of special techniques. In measuring the 'relative heterotrophic potential' of sea waters Parsons \& Strickland (I962) were the first to use a $\left[{ }^{14} \mathrm{C}\right]$-labelled organic substrate in a manner analogous to the $\left[{ }^{14} \mathrm{C}\right]$-carbonate technique developed by Steeman Nielsen (1952) for marine photosynthesis. Both these authors and Wright \& Hobbie (1965, 1966) showed that the rate of uptake of substrate by heterotrophic organisms within an aquatic population followed a typical saturation curve which could be analysed by the Michaelis-Menten equation at low concentrations $\left(>10^{-6} \mathrm{M}\right)$. At substrate concentrations $<10^{-6} \mathrm{M}$, 
much higher than exist in natural waters Wright \& Hobbie (1965, 1966) found that both fresh water lake populations and pure cultures of algae isolated from these lakes showed a second uptake mechanism based on diffusion kinetics and concluded that the algae present in the natural population were responsible for most of the uptake. Other authors (Rodhe, I955; Wood, 1956) have concluded from direct observations that algal cells in a natural community deprived of light do resort to heterotrophy.

The present paper sets out to measure the rate of uptake of a single organic substrate by a natural population and to determine if the algae present contributed to such uptake.

\section{METHODS}

The experiments outlined below were made with naturally occurring microbial populations attached to sand grains. Sand samples were taken from the littoral zone of an exposed sandy bay in a sea loch, Loch Ewe, on the west of Scotland.

Uptake experiments. The methods used were essentially those described by Wright \& Hobbie (1965), adapted to suit sand populations. Experiments were made by incubating duplicate samples of $\mathrm{ro}$ g. sand $+25 \mathrm{ml}$. filtered (Whatman GF/C grade) seawater in $60 \mathrm{ml}$. Pyrex glass-stoppered bottles. Incubations were carried out at the prevailing sea-water temperature (IO-I $4^{\circ}$ ) in dark incubators. High specific activity uniformly labelled $\left[{ }^{14} \mathrm{C}\right]$-acetate (Radiochemical Centre, Amersham, Buckinghamshire) was prepared in sterile ampoules and added in $\mu$ l. amounts at the start of incubation. Zero time controls were prepared by adding neutralized formalin immediately after addition of the isotope. Samples were shaken twice during the course of $\mathrm{I}-\mathrm{hr}$ incubations. Metabolism was stopped by adding formalin, the sand filtered off and washed with filtered sea-water. The sand samples were stored at $-15^{\circ}$ and dried before counting on aluminium planchettes in an end-window counter of known efficiency. Self absorption of radiation due to the sand was allowed for by multiplying counts/ min. by a factor of $21 \cdot 5$ (Baird \& Wetzel, 1967).

Material for autoradiography. Sand samples were prepared by incubating $2 \mathrm{~g}$. sand + Io $\mathrm{ml}$. filtered seawater in light or dark incubators with $\left[{ }^{14} \mathrm{C}\right]$-carbonate or uniformly labelled $\left[{ }^{3} \mathrm{H}\right]$-acetate, respectively. Other conditions were as previously described except that light incubations were for $5 \mathrm{hr}$ at $1000 \mathrm{ft}$.c. and at the end of incubation all sand samples were washed with distilled water. Washed sand samples were treated for $20-30 \mathrm{sec}$. at $20 \mathrm{kcyc}$./ $\mathrm{sec}$. in an ultrasonic disintegrator, then two drops of supernatant fluid were spread immediately over the surface of a slide treated with Ullrich's fixative, dried and washed.

Slides were dipped in Kodak NTB-2 liquid emulsion (diluted $\mathrm{I} / 2$ ) held at $45^{\circ}$, and exposed for 3-7 days. Detailed methodology for the use of autoradiography with micro-organisms in aquatic habitats will appear elsewhere (Brock \& Brock, I967). The photographs of autoradiograms were taken on Polaroid Type 42 film with a Polaroid MP-3 camera.

\section{RESULTS}

The microbial population. The microbial population attached to the sand grains in question was found by fluorescent microscopy to be principally composed of diatoms (Bacillariophyta; P1. I, fig. I-3) and bacteria (P1. 2, fig. 4-6). Samples were taken at low tide where both populations extend to a depth of more than $15 \mathrm{~cm}$. Additional evidence of diatoms at these depths was shown by chlorophyll and chlorophyll 
phaeopigment analyses carried out on vertical profiles of the beach by Steel \& Baird (I967). The high ratios of chlorophyll to phaeopigment found by these authors as well as uniform uptake of ${ }^{14} \mathrm{CO}_{2}$ throughout the profiles suggest algal cells in good physiological condition. However, light penetration is only $\mathrm{I} \%$ at $3 \mathrm{~mm}$. depth in quartz sand and studies of sand mixing indicate that only the top $5 \mathrm{~cm}$. regularly moves under wave action. Therefore much of the algal population may be in total darkness for periods up to many months. The situation of these algae would seem analogous to that described by other authors (Rodhe, I955; Wood, 1956) who found algal cells apparently in good physiological condition yet living in total darkness under thick ice or at considerable depths in the oceans.

The bacterial population was readily detectable to a depth of $15 \mathrm{~cm}$. as was shown by viable counts of $0.5-3 \times 10^{5} / \mathrm{g}$. sand and by staining the sand with acridine orange (Pl. 2, fig. 4-6,). If the number of objects attached to the sand grains which fluoresce green are truly all viable bacteria then the viable counts represent $0.1 \%$ or less of the total population.

Kinetic analyses. An equation for uptake of a $\left[{ }^{14} \mathrm{C}\right]$-substrate by an active population was first proposed by Steeman Nielsen (1952) and further modified by Parsons \& Strickland (1962)

$$
v=\frac{c f(S n+A)}{C \mu t}
$$

where $v$ is the velocity of substrate uptake (mg..$\left.^{-1} \mathrm{hr}^{-1}\right), c$ is the radioactivity contained in the population, $S n$ is the concentration $\left(\mathrm{mg} . \mathrm{l}^{-1}\right.$ ) of a given substrate present in the natural sample and is assumed to be of negligible proportions compared to the added substrate, $A$ the concentration (mg..$^{-1}$ ) of added substrate, $C$ the counts min. ${ }^{-1}$ from $\mathrm{I} \mu \mathrm{c}\left[{ }^{14} \mathrm{C}\right]$ in the counting assembly used, $\mu$ the number of microcuries added to the sample bottle, $t$ the incubation time (hr), and $f$ is a factor to compensate for any discrimination between $\left[{ }^{14} \mathrm{C}\right]$ and $\left[{ }^{12} \mathrm{C}\right]$ atoms, which in the present experiments is neglected. In the present experiments $c$ is the radioactivity associated with the sand grains and is multiplied by a factor of $21 \cdot 5$ (Baird \& Wetzel, 1967) to allow for selfabsorption of radiation by the sand grains and $v$, the velocity, is expressed as mg. g. $^{-1}$ sand $\mathrm{hr}^{-1}$.

The results of measuring the velocity of $\left[{ }^{14} \mathrm{C}\right]$ uptake from uniformly labelled acetate are shown from four different months in Fig. I. It can be seen that all the curves resemble each other in sharply increasing velocities at low concentrations and thereafter by a decrease in rate. As all metabolism was terminated by addition of formalin it is most likely that all the $\left[{ }^{14} \mathrm{C}\right]$ measured as uptake was no longer acetate but part of the particulate fraction of the cells in question.

The rate of uptake $(v)$ has been shown by Parsons \& Strickland (I962) to follow a saturation curve or Langmuir isotherm. If the uptake rate is proportional to time as well it is possible to apply the Michaelis-Menten equation to elucidate some of the properties of the natural population. Figure 2 shows that uptake at two substrate concentrations was proportional to time over I to $\mathrm{I} \cdot 5 \mathrm{hr}$ periods.

Conversion of the velocity curve into a linear form using a modified LineweaverBurke equation gives

$$
\frac{S n+A}{v}=\frac{K_{t}+S n}{V}+\frac{A}{V},
$$


where $v$ is the velocity of uptake at each concentration of substrate tested, $V$ the maximum rate attainable and $K_{t}$ is a constant. Substituting from (I) gives

$$
\frac{C \mu t}{c}=\frac{K_{t}+S n}{V}+\frac{A}{V}
$$

Using equation (3) a plot of $C \mu t / c$ versus $A$ can be used to solve for $K_{t}+S n$, the intercept of the straight line on the $x$-axis and $V$, the inverse of the slope of the straight line. The intercept on the ordinate, $T_{t}(\mathrm{hr})$, gives a measure of the turnover time of the natural substrate (Wright \& Hobbie, 1966).

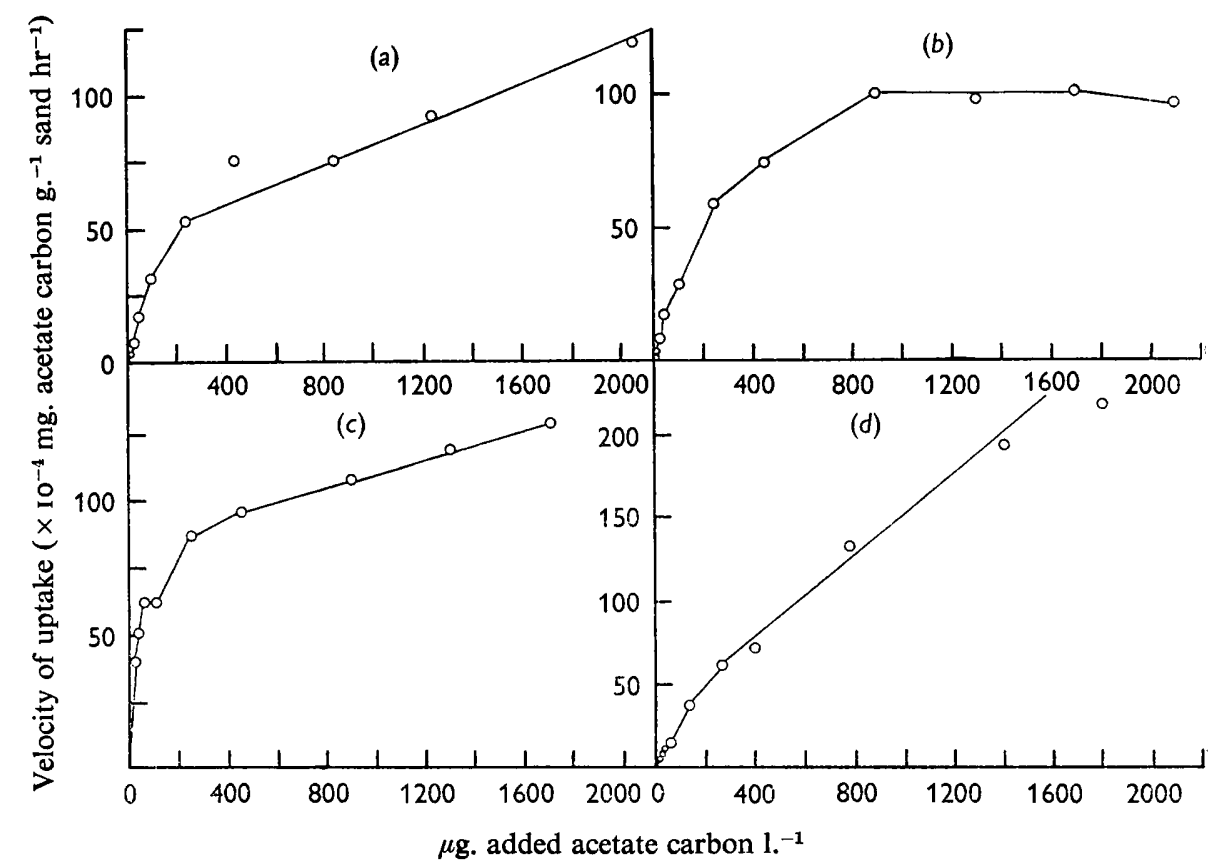

Fig. I. Uptake velocity versus substrate concentration from four different months 1966. Sand from $10 \mathrm{~cm}$. depth, from a low-water station. (a) 23 March at $10^{\circ},(b) 18$ May at $11^{\circ}$, (c) 27 July at $12.5^{\circ},(d)$ ro September at $14^{\circ}$.

The result of plotting $C \mu t / c$ against a limited range of concentrations of $A$ is shown for the 4 months in Fig. 3. Only on two occasions, I 8 May and 27 July, could all the constants be satisfactorily solved. For 23 March and to September the straight line is nearly parallel to the $x$-axis, implying that rate was proprotional to concentration. The collected results for the parameters evaluated are shown in Table $\mathrm{r}$. The values of $V$ were much greater than any of the reported results for water, a finding which can be attributed to the much larger populations in a g. of sand than in 11. of sea water.

The second uptake mechanism described by Wright \& Hobbie (1965, 1966) in planktonic populations showed a linear increase in uptake velocity at increasing substrate concentrations. The slope of this line, $k d\left(\mathrm{hr}^{-1}\right)$, was found to be identical to a similar constant derived from the kinetics of simple diffusion. On three occasions, 23 March, 27 July and ro September, our results allowed the calculation of such constants, which are recorded in Table $\mathrm{I}$. 
Wright \& Hobbie (1966) attempted to distinguish kinetically the radioactive component taken up by algae as compared to bacteria. Autoradiography (Brock \& Brock, 1966) provides a direct means of distinguishing bacterial from algal uptake. We have

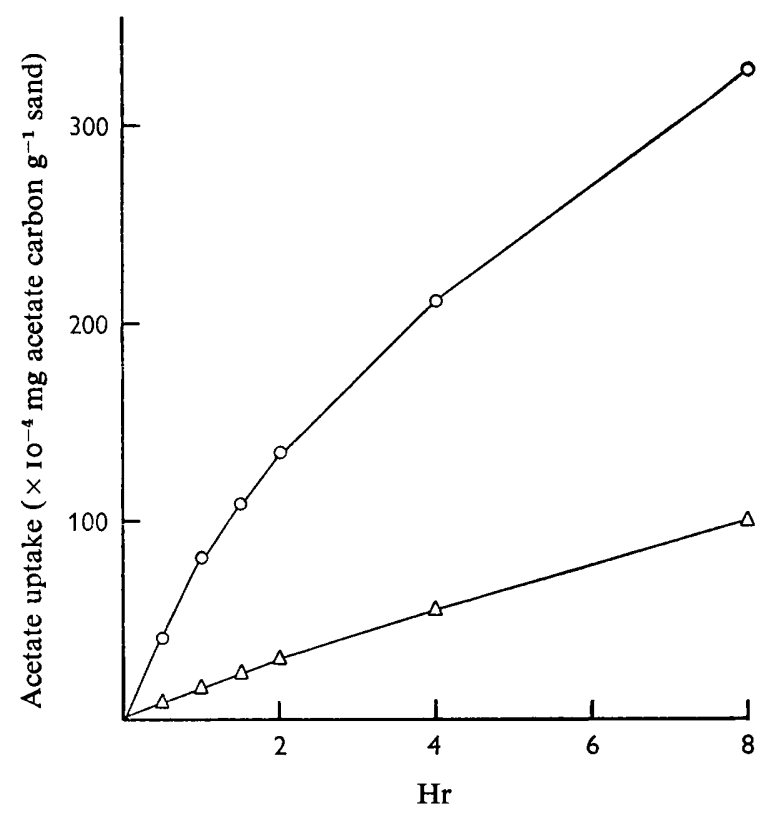

Fig. 2. Uptake at $\triangle=48 \mu \mathrm{g}$. and $O=848 \mu \mathrm{g}$. acetate-C over an $8 \mathrm{hr}$ period on 22 March I966. Temperature of incubation $10^{\circ}$. Sand from $10 \mathrm{~cm}$. depth from a low water station.

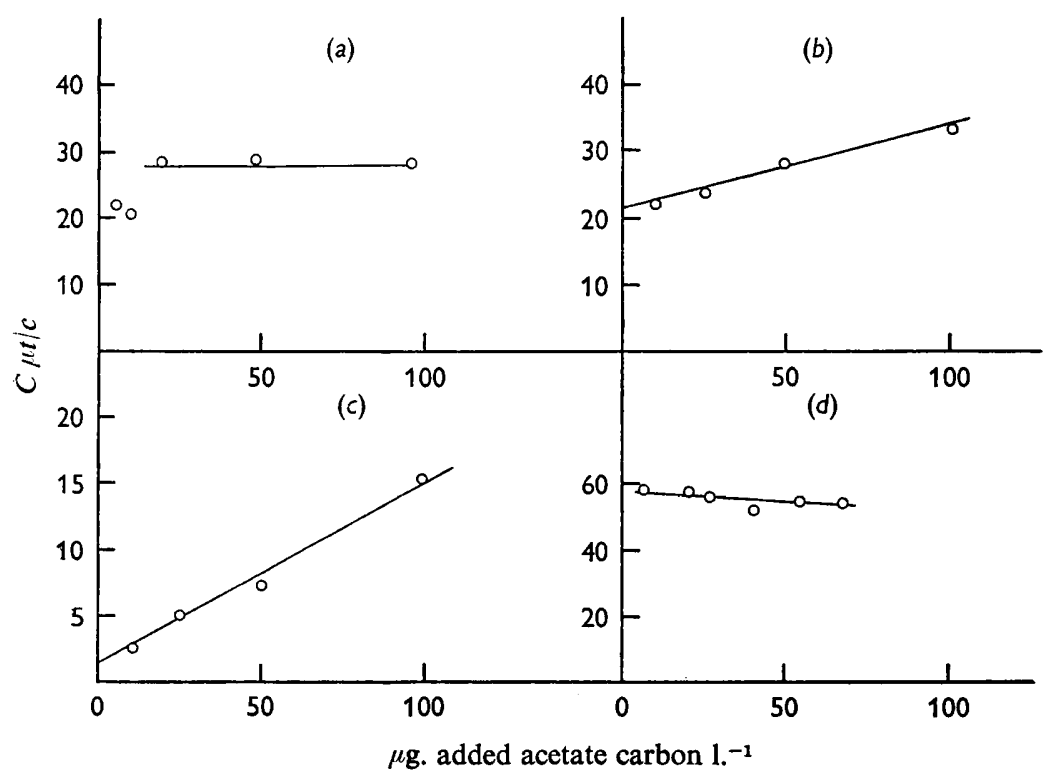

Fig. 3. Data from Fig. I. plotted by modified Lineweaver-Burke equation showing relationships between $C \mu t / c$ and added acetate. 
prepared autoradiograms of material incubated in various concentrations of $\left[{ }^{3} \mathrm{H}\right]$-acetate and $\left[{ }^{3} \mathrm{H}\right]$-glucose. We have also prepared autoradiograms of material incubated with ${ }^{14} \mathrm{CO}_{2}$ in the light.

Table I. Collected kinetic data using naturally occurring microbial populations attached to sand grains

\begin{tabular}{lcccc}
\multicolumn{1}{c}{ Dates } & 23. iii. 1966 & 18. v. 1966 & 27. vii. 1966 & 10. ix. 1966 \\
$V\left(\mathrm{mg}\right.$. acetate $\left.\mathrm{C} \times \mathrm{IO}^{-4}\right):$ & - & 80 & $71 \cdot 5$ & - \\
$K t+S(\mu \mathrm{g}$. acetate $\mathrm{C}):$ & - & 170 & 10 & - \\
$T_{t}(\mathrm{hr})$ & - & $21 \cdot 5$ & $1 \cdot 5$ & - \\
$k d\left(\mathrm{hr} \times 1 \mathrm{IO}^{-4}\right):$ & $36 \cdot 5$ & - & 26 & 122
\end{tabular}

At all concentrations of acetate or glucose, the diatoms were unlabelled, whereas many labelled bacteria and bacterial microcolonies were seen. Plate 3, fig. 7 and 8 show two labelled bacterial clusters adjacent to unlabelled diatoms when a concentration of $330 \mu \mathrm{g}$. acetate/1. was used, while Pl. 3, fig. 9 and Io show similar situations when 990 and $330 \mu \mathrm{g}$.acetate $/ 1$. were used. The diatoms in the original preparations were viable, as shown by the fact that they became labelled when incubated in the light with ${ }^{14} \mathrm{CO}_{2}$. Two labelled diatoms are seen in Pl. 3, fig. II and $\mathrm{I} 2$.

The results illustrated in the photographs are representative of those seen in a large number of microscope fields. In no case did any diatoms beome labelled when organic substrates were used.

\section{DISCUSSION}

From these results we can conclude that the assimilation of organic materials was by the bacteria associated with the sand, even when high concentrations were used. We assume that the bacteria stripped from the sand grains by brief ultrasonic treatment, and hence detected autoradiographically, were typical of those seen by fluorescence microscopy attached to the sand. The large numbers of bacteria seen on the sand particles should be emphasized. Only by reflected fluorescence microscopy can these organisms be readily seen, and virtually every sand particle observed was well colonized. Diatoms were also present on most sand particles, but seemed to be present in lower numbers than bacteria. However, Steel \& Baird (1967) found a high correlation between the chlorophyll and carbon content of this sand, suggesting that the algal biomass constituted most of the organic material present.

By use of the Wright \& Hobbie technique it was possible to calculate diffusion constants. From this and the evidence of a large algal biomass it might have been concluded that uptake of organic substances at higher concentrations was algal. Autoradiography shows that this conclusion is not justified, and emphasizes the danger of attempting to determine the presence of two components of a process by kinetic data alone. The reason for altered kinetics at higher substrate concentrations is obscure, but autoradiography shows that bacteria were responsible for all the uptake measured and hence the shape of the velocity versus concentration curves. On two of the four occasions it was possible to evaluate $V$ and $K_{t}+S n$ suggesting kinetics compatible with the Michaelis-Menten equation. On the other two occasions Fig. $3 a, d$ show a zero-order reaction, a result also found by Wright \& Hobbie (1965) for some natural populations. The reasons for these findings remain obscure.

In aquatic environments organic concentrations are generally low, although in the 
present case absorption phenomena may have led to concentrations on the sand higher than those in the free water. Bacteria are clearly able to compete successfully for the limited organic matter available, and it seems reasonable to generalize this conclusion to other aquatic situations. Aquatic bacteria have undoubtedly evolved for growth on low organic concentrations, and it seems likely that any small molecular weight organic substances which become available in the environment will be preferentially assimilated by them.

The diatoms living below the photic zone are viable as shown by autoradiography of cells exposed to $\left[{ }^{14} \mathrm{C}\right]$-carbonate in the light and also by the results of Steel \& Baird $(1967)$ on $\left[{ }^{14} \mathrm{C}\right]$ measurements on vertical profiles. The viability of these diatoms cannot be explained by heterotrophy. A parallel between this environment and finding algae in deep oceanic waters suggests that a low level of endogenous metabolism may play an important part in the survival of algal cells which had otherwise been assumed to resort to heterotrophy. In closing, we might point out that autoradiography is a powerful tool in the study of energy and trophic relations in microbial ecosystems.

We wish to acknowledge the indispensable assistance of $M$. Louise Brock in the autoradiography experiments. T. D. Brock is a Research Career Development Awardee of the U.S. Public Health Service (AI-K3-I8, 403), and his research is supported in part by a grant from the U.S. National Science Foundation (GB-5258).

\section{REFERENCES}

BAird, I. E. \& Wetzel, R. G. (I967). Method for the determination of zero thickness activity of ${ }^{14} \mathrm{C}$ labelled benthic algae in sand counted by end window geiger counter. Limnol. Oceanogr. (in Press).

Brock, T. D. \& Brock, M. L. (I966). Autoradiography as a tool in microbial ecology. Nature, Lond. 209, 734.

Brock, M. L. \& Brock, T. D. (1967). The application of auto-radiographic techniques to ecological studies. Mitt. int. Verein. theor. angew. Limnol. (in Press).

Degens, E. T., Reuter, J. H. \& SHAW, N. F. (1964). Biochemical compounds in offshore California sediments and seawaters. Geochim. cosmochim. Acta 28, 45.

Parsons, T. R. \& Strickland, J. D. H. (1962). On the production of particulate organic carbon by heterotrophic processes in sea-water. Deep Sea Res. 8, 2 I I.

RODHE, W. (I955). Can plankton production proceed during winter darkness in subarctic lakes? Verh. int. Verein. theor, angew. Limnol. 12, 117.

Siegel, A. \& Degens, E. T. (I966). Concentration of dissolved amino acids from saline waters by ligand-exchange chromatography. Science, N.Y. 151, 1098.

Sloan, P. R. \& Strickland, J. D. H. (1966). Heterotrophy of four marine phytoplankters at low substrate concentrations. J. Phycol. 2, 29.

STEel, J. H. \& BAIRD, I. E. (1967). Production ecology of a sandy beach. Limnol. Oceanogr. (in Press).

SteEman, Nielsen, E. (1952). The use of radioactive carbon for measuring organic production in the sea. J. Cons. perm. int. Explor. Mer r8, I 7 .

VACCARO, R. F. \& JANNASCH, H. W. (1966). Studies on heterotrophic activity in seawater based on glucose assimilation. Limnol. Oceanogr. Ir, 596.

Wood, E. J. F. (1956). Diatoms in the ocean deeps. Pacif. Sci. ro, 337.

WRIGHT, R. T. \& HoBbiE, J. E. (1965). The uptake of organic solutes in lake water. Limnol. Oceanogr. Io, 22.

Wright, R. T. \& HоввIE, J. E. (I966). Use of glucose and acetate by bacteria and algae in aquatic ecosystems. Ecology 47, 447. 


\section{EXPLANATION OF PLATES}

Plate I

Figs. I-3. Transmitted ultraviolet illumination showing fluorescing chloroplasts within diatoms.

Fig. I. A sand grain from 8 to Io $\mathrm{cm}$ depth. 2 May 1966. Sample taken at a low-water station.

Fig. 2. Sand grains from o to $\mathrm{I} \mathrm{cm}$ depth. 2 May 1966 . Sample from sublittoral beach.

Fig. 3. Sand grains from 8 to Io $\mathrm{cm}$ depth. 5 July 1966. Sample taken at a low-water station.

\section{Plate 2}

Figs. 4-6. Incident ultraviolet illumination with a Carl Zeiss microscope oil immersion N.A. I.3. Surfaces of sand grains from low water station, stained with acridine orange $(\mathrm{I} / 62,000 \%$, w/v) showing numerous bacteria and also diatoms. 4 September 1966.

\section{Plate 3}

Figs. 7-12. Photographed with a Carl Zeiss Phase microscope, oil immersion N.A. I'25 unstained. All photographs at same magnification. 
Journal of General Microbiology, Vol. 5I, No. I

Plate I
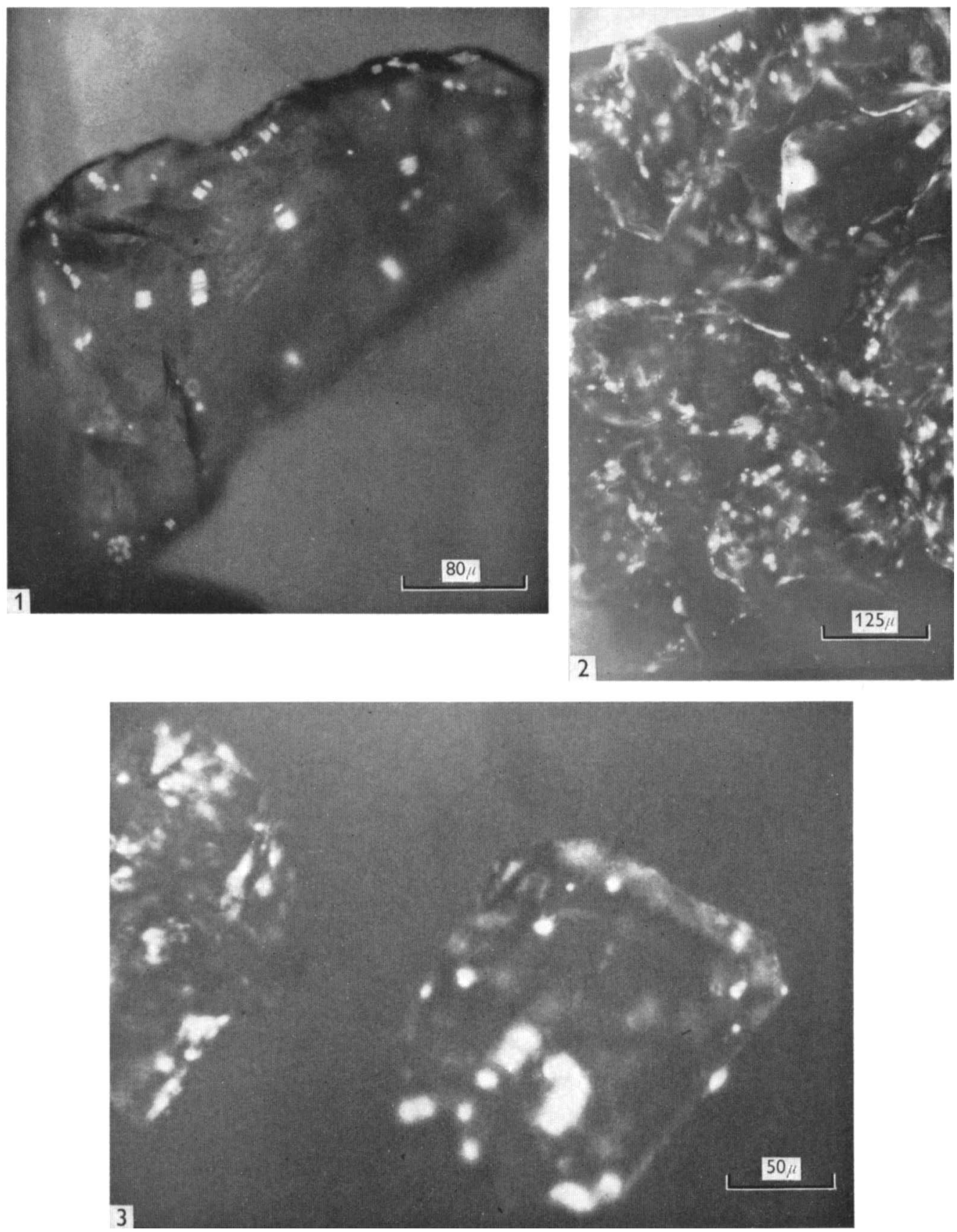

A. L. S. MUNRO AND T. D. BROCK

(Facing p. 42) 

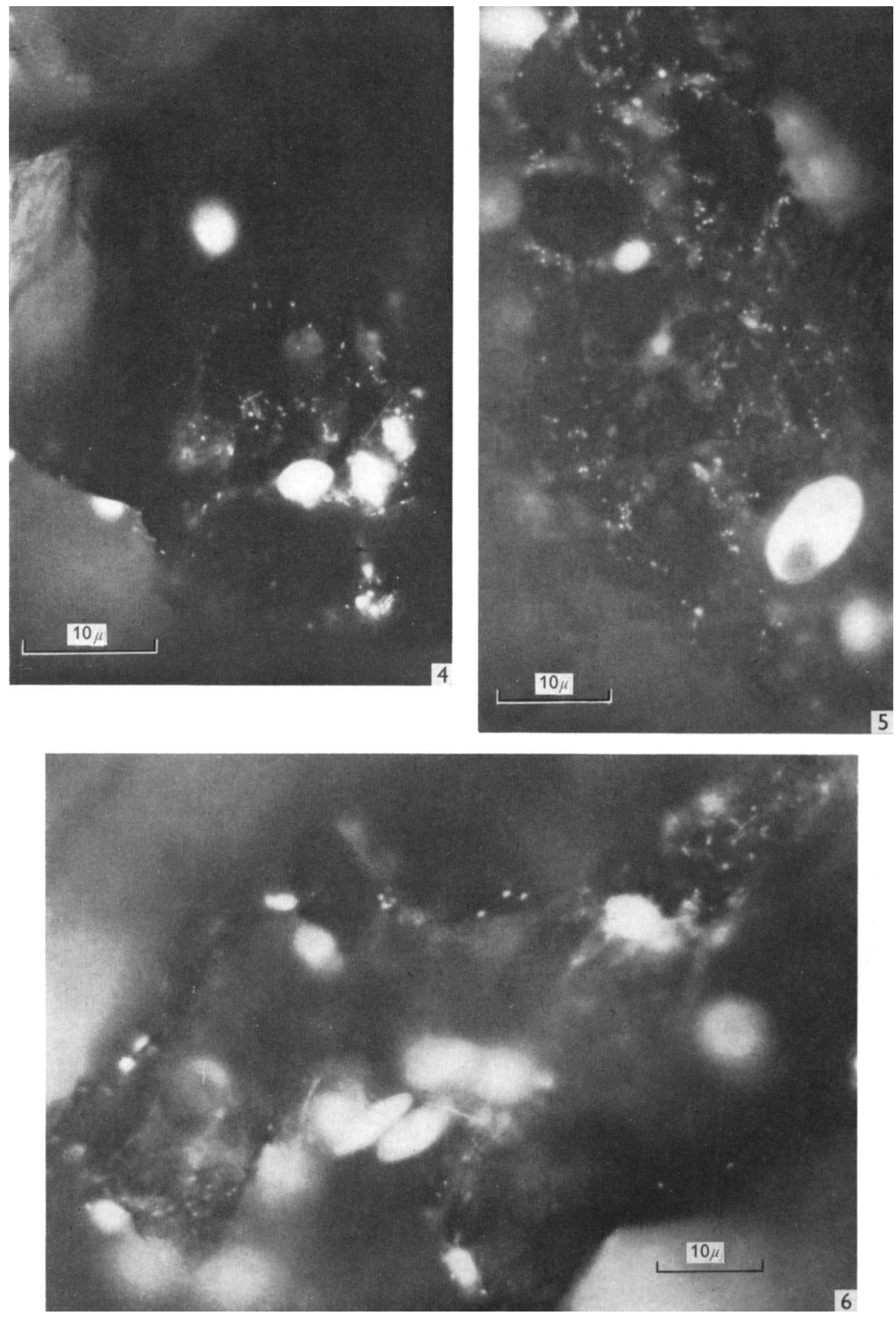

A. L. S. MUNRO AND T. D. BROCK 
Journal of General Microbiology, Vol. 5 I, No. I

Plate 3
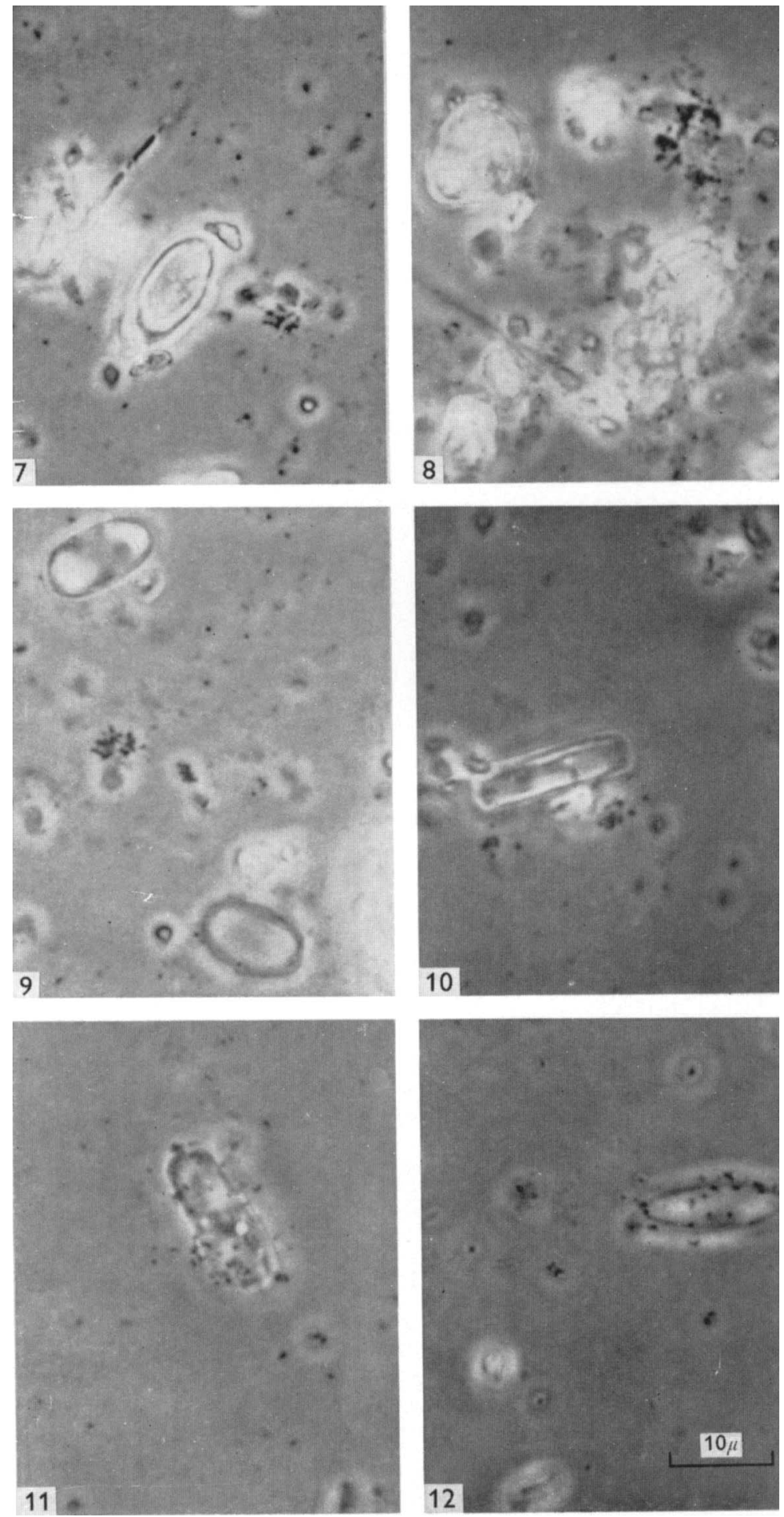

A. L. S. MUNRO AND T. D. BROCK 